\title{
RESEARCH
}

Open Access

\section{Prevalence of molecular markers of Plasmodium falciparum drug resistance in Dakar, Senegal}

\author{
Nathalie Wurtz ${ }^{1}$, Bécaye Fall², Aurélie Pascuall', Silmane Diawara ${ }^{2}$, Kowry Sow $^{2}$, Eric Baret ${ }^{1}$, Bakary Diatta ${ }^{3}$, \\ Khadidiatou B Fall ${ }^{4}$, Pape S Mbaye ${ }^{5}$, Fatou Fall, , Yaya Diémé², Christophe Rogier ${ }^{1}$, Raymond Bercion², \\ Sébastien Briolant ${ }^{1}$, Boubacar Wade ${ }^{7}$ and Bruno Pradines ${ }^{1,8^{*}}$
}

\begin{abstract}
Background: As a result of the widespread resistance to chloroquine and sulphadoxine-pyrimethamine, artemisinin-based combination therapy (ACT) (including artemether-lumefantrine and artesunate-amodiaquine) has been recommended as a first-line anti-malarial regimen in Senegal since 2006. Intermittent preventive treatments with anti-malarial drugs based on sulphadoxine-pyrimethamine are also given to children or pregnant women once per month during the transmission season. Since 2006, there have been very few reports on the susceptibility of Plasmodium falciparum to anti-malarial drugs. To estimate the prevalence of resistance to several anti-malarial drugs since the introduction of the widespread use of ACT, the presence of molecular markers associated with resistance to chloroquine and sulphadoxine-pyrimethamine was assessed in local isolates at the military hospital of Dakar.
\end{abstract}

Methods: The prevalence of genetic polymorphisms in genes associated with anti-malarial drug resistance, i.e., Pfcrt, Pfdhfr, Pfdhps and Pfmdr1, and the copy number of Pfmdr1 were evaluated for a panel of 174 isolates collected from patients recruited at the military hospital of Dakar from 14 October 2009 to 19 January 2010.

Results: The Pfcrt 76T mutation was identified in $37.2 \%$ of the samples. The Pfmdr1 86Y and 184F mutations were found in $16.6 \%$ and $67.6 \%$ of the tested samples, respectively. Twenty-eight of the 29 isolates with the $86 \mathrm{Y}$ mutation were also mutated at codon 184. Only one isolate (0.6\%) had two copies of Pfmdr1. The Pfdhfr $108 \mathrm{~N} / \mathrm{T}, 51 \mathrm{l}$ and $59 \mathrm{R}$ mutations were identified in $82.4 \%, 83.5 \%$ and $74.1 \%$ of the samples, respectively. The double mutant (108N and 51I) was detected in $83.5 \%$ of the isolates, and the triple mutant (108N, 511 and $59 R)$ was detected in $75.3 \%$. The Pfdhps $437 \mathrm{G}, 436 \mathrm{~F} / \mathrm{A}$ and $613 \mathrm{~S}$ mutations were found in $40.2 \%, 35.1 \%$ and $1.8 \%$ of the samples, respectively. There was no double mutant (437G and 540E) or no quintuple mutant (Pfdhfr 108N, 51I and 59R and Pfdhps 437G and 540E). The prevalence of the quadruple mutant (Pfdhfr 108N, 51I and 59R and Pfdhps 437G) was 36.5\%.

Conclusions: Since 2004, the prevalence of chloroquine resistance had decreased. The prevalence of isolates with high-level pyrimethamine resistance is $83.5 \%$. The prevalence of isolates resistant to sulphadoxine is $40.2 \%$. However, no quintuple mutant (Pfdhfr 108N, 51I and 59R and Pfdhps 437G and 540E), which is associated with a high level of sulphadoxine-pyrimethamine resistance, has been identified to date. The resistance to amodiaquine remains moderate.

Keywords: Malaria, Plasmodium falciparum, Anti-malarial, In vitro, Resistance, Molecular marker, Senegal

\footnotetext{
* Correspondence: bruno.pradines@free.fr

${ }^{1}$ Unité de parasitologie - Unité de recherche sur les maladies infectieuses et

transmissibles émergentes - UMR 6236, Institut de recherche biomédicale

des armées, Marseille, France

${ }^{8}$ Centre National de référence du Paludisme, Marseille, France

Full list of author information is available at the end of the article
} 


\section{Background}

During the past 20 years, many strains of Plasmodium falciparum have become resistant to chloroquine and other anti-malarial drugs [1]. One strategy for reducing malaria prevalence is the use of drugs in combination. Drug combinations help prevent the development of resistance to each component drug and reduce the overall transmission of malaria [2]. In response to increasing chloroquine resistance, Senegal in 2004 switched to sulphadoxine-pyrimethamine with amodiaquine as the first-line therapy. In 2006, artemether-lumefantrine and artesunate-amodiaquine were the forms of artemisininbased combination therapy (ACT) recommended by the $\mathrm{WHO}$ as the first-line anti-malarial regimen for managing uncomplicated malaria. Since 2006, more than 1.5 million treatments have been administered in Senegal [3]. During 2009, 184,170 doses of ACT were dispensed in Senegal [4].

Dakar, the capital city of Senegal, has an urban population of approximately 1.1 million and a suburban population of 2.3 million; the city covers the majority of the CapVert Peninsula. Malaria is transmitted in Dakar and its surrounding suburbs, with spatial heterogeneity of the human biting rate, which ranged from 0.1 to 250 bites per person per night during the rainy season from 2007 to 2010 [5]. Intermittent preventive treatment (IPT) with anti-malarial drugs given to all children and pregnant women once per month during the transmission season can provide a high degree of protection against malaria. Seasonal IPT with sulphadoxine-pyrimethamine and one dose of artesunate resulted in a $90 \%$ reduction in the incidence of clinical malaria in Senegal [6]. The combination of sulphadoxine-pyrimethamine and amodiaquine was more effective than the combination of sulphadoxinepyrimethamine and artesunate or the combination of amodiaquine and artesunate in preventing malaria [7]. During IPT with sulphadoxine-pyrimethamine and piperaquine, only $3.4 \%$ of the treated children developed malaria [8].

Since the introduction of ACT and IPT trials in Senegal, there have been very few reports on the level of resistance of $P$. falciparum to anti-malarial drugs. To determine whether parasite susceptibility has been affected by the new anti-malarial policies, a study of molecular markers was conducted with local isolates obtained from the military hospital of Dakar (Hôpital Principal de Dakar). The prevalence of genetic polymorphisms in genes associated with anti-malarial drug resistance was evaluated. The genes interest included $P$. falciparum chloroquine resistance transporter $(P f c r t)$ for chloroquine [9], P. falciparum dihydrofolate reductase (Pfdhfr) for pyrimethamine [10], P. falciparum dihydropteroate synthase (Pfdhps) for sulphadoxine [11] and P. falciparum multidrug resistance 1 $(P f m d r 1)$ for mefloquine resistance [12] and potentially for quinoline resistance [13,14].
The Pfcrt gene was firstly identified in 2000 [9]. So far at least 20 mutation points were described $[9,15,16]$, but only one is the reference mutation, the marker of chloroquine resistant phenotype: K76 that becomes T76 when mutated. This mutation is often associated with other mutations in the Pfcrt gene (Cys72Ser, Met74Ile, Asn75Glu, Ala220Ser, Gln271Glu, Asn326Ser, Ile356Thr, Arg371Ile). The role of these mutations is not yet defined. The odds ratio (OR) for failure associated with K76T mutation was 2.1 (95\% confidence interval: 1.5-3.0, meta-analysis of 13 studies) for a 14-day follow-up and 7.2 (95\%CI: 4.5-11.5, meta-analysis of 12 studies) for a 28-day follow-up [17]. However, the existence of chloroquinesusceptible strains associated with K76T mutation suggests that other genes could be involved in resistance to chloroquine.

The Ser108Asn mutation on the Pfdhfr gene is associated with resistance to anti-folate drugs [18]. The OR for sulphadoxine-pyrimethamine failure associated with Ser108Asn was 3.5 (95\%CI: 1.9-6.3, meta-analysis of 10 studies) for a 28-day follow-up [17]. The additional mutations Asn51Ile, Cys59Arg or Ile164Leu increase the level of in vitro resistance to antifolate drugs and sulphadoxine-pyrimethamine. The OR for codon 51 and 59 single mutants were 1.7 (95\% CI: 1.0-3.0) and 1.9 (95\%CI: 1.4-2.6), respectively [17]. The triple mutation $(51+59+108)$ increases the risk of in vivo resistance to sulphadoxinepyrimethamine by 4.3 (95\% CI: 3.0-6.3, meta-analysis of 22 28-day studies) [17].

Sulphones (dapsone) and sulphonamides (sulphadoxine) are inhibitors of $P$. falciparum DHPS [19]. The mutations Ser436Ala, Ser436Phe, Ala437Gly and Lys540Glu are involved in resistance to sulphadoxine [11]. The single mutation Ala437Gly and the double mutation Ala437Gly +Lys540Glu increase the risk of in vivo resistance to sulphadoxine-pyrimethamine by 1.5 (95\% CI: 1.0-2.4, meta-analysis of 12 studies) and 3.9 (95\%CI: 2.6-5.8, metaanalysis of 10 studies), respectively [17].

The quintuple mutant of Pfdhfr (codons $51+59+108$ ) plus Pfdhps (codons $437+540$ ) increases the risk of in vivo resistance to sulphadoxine-pyrimethamine by 5.2 (95\%CI: 3.2-8.8, meta-analysis of 3 studies) [17].

Pfmdr1, which encodes a $162 \mathrm{kDa}$ protein named P. falciparum homologue of the P-glycoprotein (Pgh1), is located on chromosome 5 . Field work has shown that the predictive value for chloroquine resistance and point mutations in the $P f m d r 1$ sequence resulting in amino acid changes varies depending on the geographic area $[20,21]$. Five point mutations have been described: N86Y, Y184F, S1034C, N1042D and D1246Y. Point mutations, most notably N86Y, have been associated with a decrease in the chloroquine susceptibility [22]. However, in some of these epidemiological studies, the number of chloroquinesusceptible samples is too limited to provide statistically 
meaningful analysis [21,23]. Using precautions, no or only weak relationships are established in P. falciparum between chloroquine resistance and mutations in Pfmdr1 [24]. However, the risk of therapeutic failure with chloroquine is greater for patients harbouring the N86Y mutation with an OR of 2.2 (95\%CI: 1.6-3.1) with a 14-day follow-up and 1.8 (95\%CI: 1.3-2.4) with a 28-day follow-up [17]. The combination of Pfmdr1 N86Y and Pfcrt K76T increases the risk of in vivo resistance to chloroquine by 3.9 (95\%CI: 2.6-5.8, meta-analysis of 5 studies) [17].

In addition, the risk of therapeutic failure with amodiaquine is greater for patients harbouring the N86Y mutation with an OR of 5.4 (95\%CI: 2.6-11.2, metaanalysis of six studies) [17]. This mutation increases the risk of failure with amodiaquine plus sulphadoxinepyrimethamine by 7.9 [25].

It has been shown through heterologous expression that Pfmdr1 mutations at codons 1034 and 1042 abolish or reduce the level of resistance to mefloquine [26]. Moreover, transfections with a wild-type Pfmdr 1 allele at codons 1034, 1042 and 1246 confer mefloquine resistance to susceptible parasites [27]. However, mutations at codons 1034, 1042 and 1246 in P. falciparum Pfmdr1 isolates are not sufficient to explain variations in mefloquine susceptibility [28]. Analyses of P. falciparum isolates showed an association between mutation at the codon 86 and an increase in susceptibility to mefloquine, halofantrine or artemisinin derivatives [29-31].

Amplification and overexpression of Pfmdr1 has been associated with mefloquine resistance and halofantrine decreased susceptibility in P. falciparum [32,33] Recently, Price et al. showed that amplification of Pfmdr1 is the main cause of resistance to mefloquine in $P$. falciparum [12]; the Pfmdr1 copy number could be used as a molecular marker to monitor mefloquine drug resistance in areas of emerging resistance [29]. The OR for mefloquine failure in monotherapy associated with $P f m d r 1$ amplification is 8.6 (95\%CI: 3.3-22.9) at day 28 [17]. Increased copy number from 1 to 2 is associated with a significant high risk of clinical failures with mefloquine-artesunate $(\mathrm{OR}=2.6)$ $[17,34]$ and artemether-lumefantrine [17]. Increase of Pfmdr1 copy is associated with in vitro reduced susceptibility to artemisinin derivatives [35-37]. However, increase of Pfmdr1 copy seems to be not associated with in vivo prolonged clearance time [38,39].

\section{Methods}

\section{Plasmodium falciparum isolates}

In total, 188 patients (109 males and 79 females) with malaria were recruited from 14 October 2009 to 19 January 2010 at the Hôpital Principal de Dakar. Venous blood samples were collected in Vacutainer ${ }^{\circledR}$ ACD tubes (Becton Dickinson, Rutherford, NJ, USA) prior to patient treatment. Parasitaemia ranged from $0.3 \%$ to $35 \%$ in male group and from $0.01 \%$ to $10 \%$ in female group. Informed verbal consent was obtained from patients and/ or their parents before blood collection. The study was reviewed and approved by the ethical committee of the Hôpital Principal de Dakar. Patients were treated by artemether-lumefantrine, quinine or quinine-doxycycline.

\section{Nucleic acid extraction}

Total genomic DNA of each strain was isolated using the QIAamp ${ }^{\circledR}$ DNA Mini kit according to the manufacturer's recommendations (Qiagen, Germany).

\section{Pfcrt single-nucleotide polymorphisms (SNPs)}

A 546-nucleotide fragment of the Pfcrt gene (containing codon 76) was amplified by PCR using CRTP1-sense 5'CCG TTA ATA ATA AAT ACA CGC AG-3' and CRTP1antisense 5'-CGG ATG TTA CAA AAC TAT AGT TAC C-3' primers [40]. The reaction mixture for PCR amplifications included $2.5 \mu \mathrm{l}$ of genomic DNA, $2.5 \mu \mathrm{l}$ of $10 \mathrm{X}$ reaction buffer (Eurogentec), $0.5 \mu \mathrm{M}$ of each primer, $200 \mu \mathrm{M}$ of a deoxynucleoside triphosphate mixture (dGTP, dATP, dTTP and dCTP) (Euromedex, Souffelweyersheim, France), $2.5 \mathrm{mM} \mathrm{MgCl}_{2}$ and 1 unit of RedGoldStar $^{\circledR}$ DNA polymerase (Eurogentec) in a final volume of $25 \mu \mathrm{l}$. The thermal cycler (T3 Biometra, Archamps, France) was programmed as follows: an initial $94^{\circ} \mathrm{C}$ incubation for $5 \mathrm{~min}$; 40 cycles of $94^{\circ} \mathrm{C}$ for $20 \mathrm{sec}$, $56^{\circ} \mathrm{C}$ for $20 \mathrm{sec}$ and $60^{\circ} \mathrm{C}$ for $40 \mathrm{sec}$; and a final 5-min extension step at $60^{\circ} \mathrm{C}$. The PCR products were loaded on a $1.5 \%$ agarose gel containing $0.5 \mu \mathrm{g} / \mathrm{mL}$ ethidium bromide. The PCR products were diluted 1:100 in distilled water, and $2.5 \mu \mathrm{l}$ of the final dilution was used for the second PCR. This PCR amplified a 275 bp segment around the mutation using a common inner primer CRTP3-sense 5'TGA CGA GCG TTA TAG AG-3' coupled with either CRTP4m-antisense 5'-GTT CTT TTA GCA AAA ATT G-3' (detects the $76 \mathrm{~T}$ codon) or CRTP4w-antisense 5'-GTT CTT TTA GCA AAA ATT T-3' (detects the $76 \mathrm{~K}$ codon) [15]. The reaction mixture for the PCR amplifications included $2.5 \mu \mathrm{l}$ of diluted PCR product, $2.5 \mu \mathrm{l}$ of $10 \mathrm{X}$ reaction buffer (Eurogentec), $0.5 \mu \mathrm{M}$ of each primer, $200 \mu \mathrm{M}$ deoxynucleoside triphosphate mixture (dGTP, dATP, dTTP and dCTP) (Euromedex, Souffelweyersheim, France), $1.5 \mathrm{mM} \mathrm{MgCl}_{2}$ and $0.75 \mathrm{U}$ of $\operatorname{RedGoldStar}^{\circledR}$ DNA polymerase (Eurogentec) in a final volume of $25 \mu \mathrm{l}$.

The PCR conditions were at $94^{\circ} \mathrm{C}$ for 5 min; 15 cycles at $94^{\circ} \mathrm{C}$ for $20 \mathrm{sec}, 48.5^{\circ} \mathrm{C}$ for $20 \mathrm{sec}$ and $64^{\circ} \mathrm{C}$ for $40 \mathrm{sec}$; and a final 5 min extension step at $64^{\circ} \mathrm{C}$. Purified genomic DNA from $P$. falciparum clones 3D7 (chloroquine sensitive) and W2 (chloroquine resistant) were used as positive controls, and water and human DNA were used as negative controls. The PCR products from the amplification reactions were evaluated by electrophoresis on $2 \%$ agarose gels. 


\section{Pfmdr1 SNPs}

Two primer pairs were used to amplify pfmdr 1 fragments carrying the five key codons [41]. A 590-base pair fragment was amplified with the primer pair sense 5'-AGA GAA AAA AGA TGG TAA CCT CAG-3' and antisense 5'ACC ACA AAC ATA AAT TAA CGG-3' to determine the sequences of codons 86 and 184 (MDR1-1), and a second fragment (968 base pairs) was amplified with the primer pair sense 5'-CAG GAA GCA TTT TAT AAT ATG CAT-3' and antisense 5'-CGT TTA ACA TCT TCC AAT GTT GCA-3' to determine the sequences of codons 1034, 1042, and 1246 (MDR1-2) [41]. The reaction mixture consisted of approximately $2.5 \mu \mathrm{l}$ of genomic DNA, $0.5 \mu \mathrm{M}$ of forward and reverse primers, $2.5 \mu \mathrm{l}$ of $10 \mathrm{X}$ reaction buffer (Eurogentec), $2.5 \mathrm{mM} \mathrm{MgCl}_{2}, 200 \mu \mathrm{M}$ deoxynucleoside triphosphate mixture (dGTP, dATP, dTTP and dCTP) (Euromedex, Souffelweyersheim, France) and $1 \mathrm{U}$ of RedGoldStar ${ }^{\circledR}$ DNA polymerase (Eurogentec) in a final volume of $25 \mu \mathrm{l}$. The thermal cycler (T3 Biometra) was programmed as follows: for MDR1-1, an initial $94^{\circ} \mathrm{C}$ for $5 \mathrm{~min}$; 40 cycles of $94^{\circ} \mathrm{C}$ for $30 \mathrm{sec}, 52^{\circ} \mathrm{C}$ for $30 \mathrm{sec}$ and $72^{\circ} \mathrm{C}$ for $1 \mathrm{~min}$; and a final 10 -min extension step at $72^{\circ} \mathrm{C}$; for MDR1-2, an initial $94^{\circ} \mathrm{C}$ for $5 \mathrm{~min}$; 40 cycles of $94^{\circ} \mathrm{C}$ for $30 \mathrm{sec}, 56^{\circ} \mathrm{C}$ for $1 \mathrm{~min}$ and $72^{\circ} \mathrm{C}$ for $1 \mathrm{~min} 30 \mathrm{sec}$; and a final 10 -min extension step at $72^{\circ} \mathrm{C}$ The PCR products were loaded on a $1.5 \%$ agarose gel containing $0.5 \mu \mathrm{g} / \mathrm{mL}$ ethidium bromide. Amplicons were purified using the QIAquick 96 PCR BioRobot Kit and an automated protocol on the BioRobot 8000 workstation (Qiagen, Courtaboeuf, France). The purified fragments were sequenced using the BigDye Terminator v3.1 Cycle Sequencing Kit (Applied Biosystems) using the primers described above. The sequencing reaction products were purified using the BigDye XTerminator ${ }^{\circledR}$ Purification Kit (Applied Biosystems) in accordance with the manufacturer's instructions. The purified products were sequenced using an ABI Prism 3100 analyser (Applied Biosystems). Sequences were analysed using Vector NTI advance(TM) software (version 11, Invitrogen, Cergy Pontoise, France).

\section{Pfdhfr SNP}

A 562-bp fragment corresponding to the coding region of Pfdhfr was amplified using the following primers: sense 5'ACG TTT TCG ATA TTT ATG C-3' and antisense 5' TCA CAT TCA TAT GTA CTA TTT ATT C-3' [42]. The reaction mixture contained $2.5 \mu \mathrm{l}$ of genomic DNA, $2.5 \mu \mathrm{l}$ of $10 \mathrm{X}$ reaction buffer (Eurogentec), $0.5 \mu \mathrm{M}$ each primer, $2.5 \mathrm{mM} \mathrm{MgCl}, 200 \mu \mathrm{M}$ deoxynucleoside triphosphate mixture (dGTP, dATP, dTTP and dCTP) (Euromedex, Souffelweyersheim, France) and $1 \mathrm{U}$ of RedGoldStar ${ }^{\circledR}$ DNA polymerase (Eurogentec) in a final volume of $25 \mu \mathrm{l}$. The PCR conditions were as described in [42]. The amplified fragments were purified, sequenced (with the primers used for PCR) and analysed as described above.

\section{Pfdhps SNP}

A 672-bp fragment corresponding to the coding region of Pfdhps was amplified using the following primers: sense 5/-GTT GAA CCT AAA CGT GCT GT-3/ and antisense 5/-TTC ATC ATG TAA TTT TTG TTG TG3/ [42]. The fragment was amplified as described for pfdhfr, and the PCR conditions were as described in [42]. The amplified fragments were purified, sequenced (with the primers used for PCR) and analysed as described above.

\section{Copy number of Pfmdr1}

The Pfmdr1 copy number was estimated by TaqMan real-time PCR (7900HT Fast Real-Time PCR system, Applied Biosystems, Courtaboeuf, France) using the single-copy gene $\beta$-tubulin (PF10_0084) as a reference. The following previously reported oligonucleotide primers and probes were used with slight modifications [12]: 5'-TGC ATC TAT AAA ACG ATC AGA CAA A3', 5'-TCG TGT GTT CCA TGT GAC TGT-3' and 5'VIC- TTT AAT AAC CCT GAT CGA AAT GGA ACC TTT G-TAMRA-3' for Pfmdr1 and 5'- TGA TGT GCG CAA GTG ATC C-3', 5'-TCC TTT GTG GAC ATT CTT CCT C-3' and 5'-FAM- TAG CAC ATG CCG TTA AAT ATC TTC CAT GTC T-TAMRA-3' for $\beta$-tubulin (Eurogentec, Angers, France). Individual PCR reactions were carried out using 1X TaqMan Universal PCR Master Mix (Applied Biosystems), $900 \mathrm{nM}$ forward primer, $900 \mathrm{nM}$ reverse primer, $250 \mathrm{nM}$ Taqman probe and $5 \mu \mathrm{l}$ of template DNA in a final volume of $25 \mu \mathrm{l}$. The reaction mixtures were prepared at $4{ }^{\circ} \mathrm{C}$ in a 96-well optical reaction plate (Applied Biosystems) covered with optical adhesive covers (Applied Biosystems). The thermal cycling conditions were $50^{\circ} \mathrm{C}$ for $2 \mathrm{~min}, 95^{\circ} \mathrm{C}$ for $10 \mathrm{~min}$, and 50 cycles of $95^{\circ} \mathrm{C}$ for $15 \mathrm{~s}$ and $60^{\circ} \mathrm{C}$ for $1 \mathrm{~min}$. Each sample was assayed in triplicate, and the data were analysed with SDS software 2.2.1 (Applied Biosystems). The PCR efficiencies of all primer pairs were evaluated using a dilution series of $P$. falciparum 3D7 genomic DNA and were found to be sufficiently close to obviate the need for any correction factor. Therefore, the $2^{-\Delta \Delta C t}$ method of relative quantification was used and adapted to estimate the copy number of the pfmdr1 gene, where $\Delta \Delta \mathrm{Ct}=\left(\mathrm{Ct}_{p f m d r 1}-\mathrm{Ct}_{\beta-}\right.$ tubuline $)_{\text {sample }}-\left(\mathrm{Ct}_{\text {pfmdr1 }}-\mathrm{Ct}_{\beta \text {-tubuline }}\right)_{\text {calibrator. Genomic }}$ DNA extracted from the P. falciparum 3D7 strain, which has a single copy of each gene, was used as a calibrator, and $\beta$-tubulin served as the control housekeeping gene in all experiments.

\section{Results}

One hundred and eighty-eight patients were recruited for the study at the Hôpital Principal de Dakar. Gene polymorphisms were evaluated in 174 isolates that were slide-positive for $P$. falciparum. 
Pfcrt was examined in 164 of the P. falciparum-positive samples. At the Pcrt gene, the codon 76 (K76T) mutation was identified in $37.2 \%$ of the samples. One sample (0.6\%) was mixed, yielding both K76 and 76T.

The results for Pfmdr1 polymorphisms are shown in Table 1. The codon 86 (N86Y) mutation was identified in $16.6 \%$ of the tested samples. One isolate $(0.6 \%)$ was mixed, yielding both N86 and 86Y. A mutation in codon 184 (Y184F) was identified in $67.6 \%$ of the isolates. Twenty-eight of the 29 isolates with the $86 \mathrm{Y}$ mutation were also mutated at codon 184 (184F). No new SNP was detected in Pfmdr1 gene. Only one isolate $(0.6 \%)$ harboured two copies of $p f m d r 1$.

The results for Pfdhfr polymorphisms are presented in Table 2. There was a mutation in $82.4 \%$ of the samples for codon $108(\mathrm{~S} 108 \mathrm{~N} / \mathrm{T}$ ) (only 1/140 S108N/T was $\mathrm{S} 108 \mathrm{~T}$ ), in $83.5 \%$ for codon 51 (N51I) and in $74.1 \%$ for codon 59 (C59R). Nine samples (5.2\%), one sample (0.6\%) and 19 samples (11.2\%) were mixed, yielding both S108 and 108N, N51 and 51I, and C59 and 59R, respectively. The double mutant (108N and 51I) was detected in $83.5 \%$ of the isolates, and the triple mutant $(108 \mathrm{~N}, 51 \mathrm{I}$ and 59R) was detected in $75.3 \%$. Two mutants were detected for codon 16 (A16V).

The results for Pfdhps polymorphisms are presented in Table 3. There was a mutation in $40.2 \%$ of the samples for codon 437 (A437G), in 35.1\% for codon 436 (S436F/A) and in $1.8 \%$ for codon 613 (A613S). No mutant was detected for codons 540 and 581 .

There was no double mutant (437G and 540E) and no quintuple mutant (Pfdhfr 108N, 51I and 59R and Pfdhps $437 \mathrm{G}$ and $540 \mathrm{E})$. The prevalence of the quadruple mutant (Pfdhfr 108N, 51I and 59R and Pfdhps 437G) was 36.5\%.

\section{Discussion}

In response to increasing chloroquine resistance, Senegal in 2004 switched to sulphadoxine-pyrimethamine with amodiaquine as the first-line therapy. In 2006, artemetherlumefantrine and artesunate-amodiaquine were the forms of artemisinin-based combination therapy (ACT) recommended by the $\mathrm{WHO}$ as the first-line anti-malarial regimen for managing uncomplicated malaria.

Table 1 Number (no) and frequency (\%) of the Pfmdr1 mutations (codons 86, 184, 1034, 1042, and 1246)

\begin{tabular}{lcccc}
\hline Codon & No & $\begin{array}{c}\text { Wild type } \\
\text { no (\%) }\end{array}$ & $\begin{array}{c}\text { Mutated } \\
\text { no (\%) }\end{array}$ & $\begin{array}{c}\text { Wild type/ } \\
\text { Mutated no (\%) }\end{array}$ \\
\hline N86Y & 174 & $144(82.8)$ & $29(16.6)$ & $1(0.6)$ \\
Y184F & 173 & $56(32.4)$ & $117(67.6)$ & $0(0)$ \\
S1034C & 163 & $163(100)$ & $0(0)$ & $0(0)$ \\
N1042D & 170 & $170(100)$ & $0(0)$ & $0(0)$ \\
D1246Y & 168 & $168(100)$ & $0(0)$ & $0(0)$ \\
\hline
\end{tabular}

Table 2 Number (no) and frequency (\%) of the Pdhfr mutations (codons 108, 51, 59, 16, and 164)

\begin{tabular}{lcccc}
\hline Codon & No & $\begin{array}{c}\text { Wild type } \\
\text { no (\%) }\end{array}$ & $\begin{array}{c}\text { Mutated } \\
\text { no (\%) }\end{array}$ & $\begin{array}{c}\text { Wild type/ } \\
\text { Mutated no (\%) }\end{array}$ \\
\hline S108N/T* & 170 & $21(12.4)$ & $140^{*}(82.4)$ & $9(5.2)$ \\
N51I & 170 & $27(15.9)$ & $142(83.5)$ & $1(0.6)$ \\
C59R & 170 & $25(14.7)$ & $126(74.1)$ & $19(11.2)$ \\
A16V & 158 & $155(98.1)$ & $2(1.3)$ & $1(0.6)$ \\
I164L & 170 & $169(99.4)$ & $1(0.6)$ & $0(0)$ \\
\hline
\end{tabular}

*One was 108T.

Mutations in Pfcrt have been shown to be correlated with chloroquine resistance in different parts of the world [43]. The prevalence of the Pfcrt 76T mutation decreased since 2004 in Dakar. In 2000-2001 in Guediawaye, a suburb of Dakar, a prevalence of $92 \%$ of $76 \mathrm{~T}$ was observed in pregnant women with malaria [44]. In Pikine, another suburb of Dakar, the prevalence of $76 \mathrm{~T}$ was $79 \%$ in 2000 [45], 63.9\% in 2001 [46] and 59.5\% in 2004 [47]. In 2002, the prevalences of in vitro resistance to chloroquine and of Pfcrt 76T mutation were 52\% and 65\%, respectively, in patients hospitalized for malaria at the Hôpital Principal de Dakar [48]. In 2001-2002, the prevalence of the pfcrt $76 \mathrm{~T}$ mutation was $75.8 \%$ in pregnant women taking chloroquine prophylaxis in Thiadiaye $(84 \mathrm{~km}$ southeast of Dakar) [49]. In Dielmo (280 km southeast of Dakar), the in vitro resistance to chloroquine regularly increased from $32 \%$ in 1995 to $55 \%$ in 1999 [50-53].

In this study, the Pfcrt 76T mutation was identified in $37.2 \%$ of the patients recruited from October 2009 to January 2010 in the Hôpital Principal de Dakar. These data are consistent with previous works on molecular resistance and on in vitro or ex vivo susceptibility in Dakar in 2009 ( $22 \%$ of isolates exhibiting chloroquine resistance) [54] and in Thies in 2007 (23\% of isolates exhibiting chloroquine resistance) [55].

This decrease in chloroquine resistance parallels the withdrawal of chloroquine treatment and the introduction of ACT in 2002 in Senegal. However, in 2003, chloroquine was still being administered to patients. The prevalence of chloroquine in the urine ranged from

Table 3 Number (no) and frequency (\%) of the Pfdhps mutations (codons 437, 436, 540, 581, and 613)

\begin{tabular}{lcccc}
\hline Codon & No & $\begin{array}{c}\text { Wild type } \\
\text { no (\%) }\end{array}$ & $\begin{array}{c}\text { Mutated } \\
\text { no (\%) }\end{array}$ & $\begin{array}{c}\text { Wild type/ } \\
\text { Mutated no (\%) }\end{array}$ \\
\hline A437G & 174 & $104(59.8)$ & $70(40.2)$ & $0(0)$ \\
S436F/A & 174 & $112(64.3)$ & $61(35.1)$ & $1(0.6)$ \\
K540E & 174 & $174(100)$ & $0(0)$ & $0(0)$ \\
A581G & 174 & $174(100)$ & $0(0)$ & $0(0)$ \\
A613S & 171 & $168(98.2)$ & $3(1.8)$ & $0(0)$ \\
\hline
\end{tabular}


$14.5 \%$ to $47.5 \%$ in two- to nine-year-old children from northern Senegal and from $9.0 \%$ to $21.4 \%$ in children from southern Senegal [56]. In 2006, Senegal reported 10.6\% chloroquine use and 9.7\% ACT use [57]. Since 2006, more than 1.5 million ACT treatments have been administered in Senegal [3], and 184,170 doses of ACT were dispensed in 2009 [4]. A reduction in chloroquine resistance was also reported in Malawi after the withdrawal of chloroquine treatment [58]. This observation prompted an in vivo chloroquine study in Malawi five years later, in which chloroquine was found to be $99 \%$ effective [59]. The rapid dissemination of chloroquine resistance in Dielmo, despite strictly controlled anti-malarial drug use, argues against the re-introduction of chloroquine at least in monotherapy in places where the resistant allele has dropped to very low levels following the discontinuation of chloroquine treatment [60]. It took 407 chloroquine treatments (1.6 treatment courses/person/year) in the community to raise the prevalence of the Pfcrt 76T mutation from an 89\% during the first year of re-introduction of chloroquine (1993-1994) to $46 \%$ in 1995 . Increased selective pressure (2752 treatments during the period 1995-1999) did not increase the prevalence of Pfcrt 76T or increased the in vitro resistance to chloroquine, but this increased selective pressure increased the incidence of clinical malaria for patients within seven days of chloroquine treatment from $2.6 \%$ in 1995 to $13 \%$ in 1999 .

The Pfdhfr $108 \mathrm{~N}$ mutation has been shown to be correlated with in vitro and in vivo resistance to pyrimethamine $[10,17]$. The OR for sulphadoxine-pyrimethamine failure associated with Ser108Asn was 3.5 (95\%CI: 1.9-6.3, metaanalysis of 10 studies) for a 28-day follow-up [17]. The additional mutations Asn51Ile, Cys59Arg or Ile164Leu increase the level of in vitro resistance to anti-folate drugs and sulphadoxine-pyrimethamine. The OR for codon 51 and 59 single mutants were 1.7 (95\%CI: 1.0-3.0) and 1.9 (95\%CI: 1.4-2.6), respectively [17]. In 2009, the prevalence of Pfdhfr $108 \mathrm{~N}$ was $82.4 \%$ in patients with malaria who were treated at the Hôpital Principal de Dakar. The triple mutation $(51+59+108)$ increases the risk of in vivo resistance to sulphadoxine-pyrimethamine by 4.3 (95\%CI: 3.0-6.3, meta-analysis of 22 28-day studies). Isolates carrying a combination of three mutations (108N, 51I and 59R) associated with high-level pyrimethamine resistance represented $75.3 \%$. In 2002, in the same hospital, the prevalence of Pfdhfr $108 \mathrm{~N}$ was $65 \%$, and triple mutants were identified in $50 \%$ of the isolates [48]. In 2003, the prevalence of mutations in Pfdhfr codon 108 was $78 \%$ in Pikine, and the prevalence of the triple mutant was $61 \%$ [61]. In 2007 in Keur Soce, a rural area, triple mutant was identified in $67 \%$ of patients treated with sulphadoxinepyrimethamine combined with amodiaquine [8].

The Pfdhps 437G mutation has been shown to be correlated with in vitro and in vivo resistance to sulphadoxine
$[11,17]$. The single mutation Ala437Gly and the double mutation Ala437Gly+Lys540Glu increase the risk of in vivo resistance to sulphadoxine-pyrimethamine by 1.5 (95\%CI: 1.0-2.4, meta-analysis of 12 studies) and 3.9 (95\% CI: 2.6-5.8, meta-analysis of 10 studies), respectively [17]. In 2009, the prevalence of the Pfdhps 437G mutation was $40.4 \%$ in patients with malaria who were treated at the Hôpital Principal de Dakar. However, there was no isolate carrying the double mutation (437G and 540E) that is associated with high-level sulphadoxine resistance. The mutation of codon 613 (A613S) (1.8\%) was very rare in Africa. In 2002, in the same hospital, only $20 \%$ of isolates harboured the Pfdhps 437G mutation [48]. In 2003, the mutation rate in Pfdhps codon $437 \mathrm{G}$ was $40 \%$ in Pikine [61]. Several studies from 2006 to 2008 in Senegal showed that the prevalence of Pfdhps $437 \mathrm{G}$ significantly increased after intermittent preventive treatment of infants with sulphadoxine-pyrimethamine [8,62]. Given the prevalences of the triple and quadruple mutants in the population of Dakar (75.3\% Pfdhfr 108N, 51I and 59R triple mutant and $36.5 \%$ quadruple mutant Pfdhfr 108N, 51I and 59R and Pfdhps 437G), the use of sulphadoxine-pyrimethamine as an intermittent preventive treatment must be monitored. Encouragingly, no quintuple mutant (Pfdhfr 108N, 51I and 59R and Pfdhps 437G and 540E), which is associated with high-level sulphadoxine-pyrimethamine resistance, has been identified to date. However, the single use of sulphadoxine-pyrimethamine as seasonal IPT must be inadvisable: sulphadoxine-pyrimethamine must be associated with amodiaquine, artesunate or piperaquine for instance $[7,8]$.

Only one isolate $(0.6 \%)$ had two copies of Pfmdr1. In Asia, amplification of Pfmdr1 is associated with mefloquine resistance in vitro and in vivo $[12,29,63]$. The role of increased copy number in mefloquine resistance in Africa remains controversial. Isolates with a duplicated Pfmdr1 gene circulate in West Africa but are relatively rare [64]. Only one published clinical failure for mefloquine in West Africa was found to be associated with in vitro resistance and amplification of Pfmdr1 [65]. In addition, amodiaquine resistance is not related to the amplification of Pfmdr1 [66]. The role of the amplification of Pfmdr1 in resistance to artemether-lumefantrine in Africa is still debated. It seems that no Pfmdr1 gene amplification was associated with artemether-lumefantrine failures in Africa [67], whereas a copy number $\geq 4$ is associated with reduced in vitro susceptibility to lumefantrine [68]. In 2009, in Dakar, only $1 \%$ of the isolates presented reduced in vitro susceptibility to lumefantrine [44], and this prevalence did not increase in Senegal after the introduction of ACT. In 1996, 6\% of isolates from Dielmo were resistant in vitro to lumefantrine [69]. In recent years, the efficacy of artemether-lumefantrine in several trials in Senegal has ranged from 96 to $100 \%$ [70-72]. 
The prevalences of the Pfmdr1 mutations $86 \mathrm{Y}$ and $184 \mathrm{~F}$ were $16.6 \%$ and $67.6 \%$, respectively. No isolate carried a mutation in codons 1034, 1042 or 1246. In 2000 and 2001, prevalences of $31 \%$ and 30.6 were observed for Pfmdr1 $86 \mathrm{Y}$ in Pikine [45,46]. The role of polymorphism in Pfmdr1 is still debated. Point mutations in Pfmdr1, most notably at codon 86 , have been found to be associated with decreased chloroquine susceptibility [73]. Nevertheless, this association is not a consistent finding [24]. The Pfmdr1 86Y mutation also has been found to be associated with increased susceptibility to mefloquine or artemisinin [29-31]. This association, too, is not a consistent finding [63]. In addition, no clear association between the Pfmdr1 184F mutation and mefloquine failure has been established, although this allele is widespread in Cambodia [74]. The Pfmdr1 $86 \mathrm{Y}$ mutation has also been shown to be associated with in vivo resistance to amodiaquine in recrudescence after monotherapy with amodiaquine [75] or after combination therapy with artesunate-amodiaquine [76]. The Pfmdr1 $1246 \mathrm{Y}$ mutation has also been found to be associated with in vitro resistance to amodiaquine [77] and with recrudescent infection after treatment with amodiaquine or amodiaquine-artesunate [76,78]. In a meta-analysis, the Pfmdr1 $86 \mathrm{Y}$ mutation was demonstrated to be associated with amodiaquine failure, with an odds ratio of 5.4 [17]. Based on this hypothesis, the $16.6 \%$ prevalence of Pfmdr1 of $86 \mathrm{Y}$ predicts that $16.6 \%$ of isolates would be resistant to amodiaquine in 2009 in Senegal. In 2009, in Dakar, only $6 \%$ of isolates showed in vitro reduced susceptibility to monodesethylamodiaquine, the active metabolite of amodiaquine [54]. The resistance to amodiaquine has remained low even after the introduction of artesunateamodiaquine in 2006 in Senegal relative to the resistance prevalences of Dielmo in 1996 and 1999 (0\%) [50,79] and Mlomp in Casamance, south-western Senegal, in 2004 (5\%) [80]. The artesunate-amodiaquine-associated cure rates were $>99.3 \%$ in Mlomp and Keur-Socé when administered either as a single daily dose or two daily doses [81]. The fixed-dose combination of artesunate-amodiaquine (ASAQ) exhibits a cure rate $>98.5 \%$ [82]. The cure rates were $100 \%$ in the populations experiencing a second or third episode of uncomplicated malaria following treatment with ASAQ [69]. However, ACT efficacy and resistance must be monitored because the first clinical failures, or at least extended parasite clearance times, have been described in Cambodia $[38,83]$. In this context, it is important to implement in vitro and in vivo surveillance programmes, such as those championed by the Worldwide Antimalarial Resistance Network $[84,85]$.

Since 2004, the prevalence of chloroquine resistance has decreased, but the data argue against the re-introduction of chloroquine at least in mono-therapy in places where the resistant allele has dropped to very low levels following discontinuation of chloroquine treatment. The prevalence of isolates resistant to pyrimethamine is high (82.4\%), with $75.3 \%$ of parasites exhibiting high-level pyrimethamine resistance. The prevalence of isolates resistant to sulphadoxine was $40.2 \%$. However, no quintuple mutant (Pfdhfr $108 \mathrm{~N}, 51 \mathrm{I}$ and 59R and Pfdhps 437G and 540E), which is associated with high-level sulphadoxine-pyrimethamine resistance, has been identified to date. The resistance to amodiaquine remains moderate. Intensive surveillance of $P$. falciparum susceptibility to anti-malarial drugs must be conducted regularly in Senegal. However, maximizing the efficacy and longevity of ACT as a tool to control malaria will critically depend on pursuing intensive research into identifying in vitro markers as well as implementing in vitro and in vivo surveillance programs. In this context, there is a need to identify molecular markers that predict ACT resistance which can provide an active surveillance method to monitor temporal trends in parasite susceptibility.

\section{Consent}

The study was reviewed and approved by the ethics commission of Hôpital Principal de Dakar.

\section{Competing interests}

The authors declare that they have no competing interests.

\section{Authors' contributions}

NW, AP, EB and SB carried out the molecular genetic studies. BF, SD, SD, TD, $B D, K B F, P S M$ and FF carried out diagnostic tests, monitored the patients, collected clinical and epidemiological data and drafted the manuscript. CR, $\mathrm{RB}, \mathrm{BW}$ and BP conceived and coordinated the study. SB, CR and BP analysed the data. NW, AP, SB and BP drafted the manuscript. All authors read and approved the final manuscript.

\section{Acknowledgements}

The authors thank Ndeye Fatou Diop and Maurice Gomis for technical support and the staff of the clinical units. This work was supported by the Etat Major des Armées Françaises (grant schema directeur paludisme LR 607).

\section{Author details}

'Unité de parasitologie - Unité de recherche sur les maladies infectieuses et transmissibles émergentes - UMR 6236, Institut de recherche biomédicale des armées, Marseille, France. ${ }^{2}$ Laboratoire d'étude de la chimiosensibilité du paludisme, Fédération des laboratoires, Hôpital Principal de Dakar, Dakar, Sénégal. ${ }^{3}$ Service de réanimation médicale, Hôpital Principal de Dakar, Dakar, Sénégal. ${ }^{4}$ Service de pathologie infectieuse, Hôpital Principal de Dakar, Dakar, Sénégal. ${ }^{5}$ Département de médecine interne et spécialités médicales de pathologie tropicale, Hôpital Principal de Dakar, Dakar, Sénégal. 'Service interne d'hépato-gastroentérologie, Hôpital Principal de Dakar, Dakar, Sénégal. ${ }^{7}$ Chefferie, Hôpital Principal de Dakar, Dakar, Sénégal. ${ }^{8}$ Centre National de référence du Paludisme, Marseille, France.

Received: 25 February 2012 Accepted: 2 June 2012

Published: 13 June 2012

\section{References}

1. Le Bras J, Musset L, Clain J: Antimalarial drug resistance. Med Mal Infect 2006, 36:401-405.

2. White NJ: Preventing antimalarial drug resistance through combinations. Drug Resist Updat 2001, 1:3-9.

3. Ndiaye JLA, Faye B, Gueye A, Tine R, Ndiaye D, Tchania C, Ndiaye I, Barry A, Cisse B, Lameyre V, Gaye O: Repeated treatment of recurrent uncomplicated Plasmodium falciparum malaria in Senegal with fixed- 
dose artesunate plus amodiaquine versus fixed-dose artemether plus lumefantrine: a randomized, open-label trial. Malar J 2011, 10:237.

4. Thiam S, Thior M, Faye B, Diouf ML, Diouf MB, Diallo I, Fall FB, Ndiaye JL, Albertini $A$, Lee $E$, Jorgensen $P$, Gaye $O$, Bell D: Major reduction in antimalarial drug consumption in Senegal after nation-wide introduction of malaria rapid diagnostic tests. PLoS One 2011, 6:18419.

5. Gadiaga L, Machault V, Pagès F, Gaye A, Jarjaval F, Godefroy L, Cissé B, Lacaux JP, Sokhna C, Trape JF, Rogier C: Conditions of malaria transmission in Dakar from 2007 to 2010. Malar J 2011, 10:312.

6. Cissé B, Sokhna C, Boulanger D, Milet J, Ba EH, Richardson K, Hallett R, Sutherland C, Simondon K, Simondon F, Alexander N, Gaye O, Targett G, Lines J, Greenwood B, Trappe JF: Seasonal intermittent preventive treatment with artesunate and sulfadoxine-pyrimethamine for prevention of malaria in Senegalese children: a randomized, placebocontrolled, double-blind trial. Lancet 2006, 367:659-667.

7. Sokhna C, Cissé B, Ba EH, Milligan P, Hallett R, Sutherland C, Gaye O, Boulanger D, Simondon K, Simondon F, Targett G, Lines J, Greenwood B, Trape JF: A trial of the efficacy, safety and impact on drug resistance of four drug regimens for seasonal intermittent preventive treatment for malaria in Senegalese children. PLoS One 2008, 3:1471.

8. Cissé B, Cairns M, Faye E, NDiaye O, Faye B, Cames C, Cheng Y, NDiaye M, Colle Lo A, Simondon K, Trape JF, Faye O, NDiaye JL, Gaye O, Greenwood B, Milligan P: Randomized trial of piperaquine with sulfadoxinepyrimethamine or dihydroartemisinin for malaria intermittent preventive treatment in children. PLoS One 2009, 4:7164.

9. Fidock DA, Nomura T, Talley AK, Cooper RA, Dzekunov SM, Ferdig MT, Ursos LMB, Sidhu ABS, Naudé B, Deitsch KW, Su XZ, Wootton JC, Roepe PD, Wellems TE: Mutations in the $P$. falciparum digestive vacuole transmembrane protein PfCRT and evidence for their role in chloroquine resistance. $\mathrm{Mol}$ Cell 2000, 6:861-871.

10. Zolg JW, Plitt JR, Chen GX, Palmer S: Point mutations in the dihydrofolate reductase-thymidylate synthase gene as the molecular basis for pyrimethamine resistance in Plasmodium falciparum. Mol Biochem Parasitol 1989, 36:253-262.

11. Wang P, Read M, Sims PF, Hyde JE: Sulfadoxine resistance in the human malaria parasite Plasmodium falciparum is determined by mutations in dihydropteroate synthetase and an additional factor associated with folate utilisation. Mol Microbiol 1997, 23:979-986.

12. Price RN, Uhlemann AC, Brockman A, McReady R, Ashley E, Phaipun L, Patel R, Laing K, Looareesuwan S, White NJ, Nosten F, Krishna S: Mefloquine resistance in Plasmodium falciparum and increased pfmdr1 gene copy number. Lancet 2004, 364:438-447.

13. Henry M, Alibert S, Orlandi-Pradines E, Bogreau H, Fusai T, Rogier C, Barbe J, Pradines B: Chloroquine resistance reversal agents as promising antimalarial drugs. Curr Drug Targets 2006, 7:935-948.

14. Henry M, Alibert S, Rogier C, Barbe J, Pradines B: Inhibition of efflux of quinolines as new therapeutic strategy in malaria. Curr Top Med Chem 2008, 8:563-578.

15. Nagesha HS, Casey GJ, Rieckmann H, Fryauff DJ, Laksana BS, Reeder JC, Maguire JD, Baird J: New haplotypes of the Plasmodium falciparum chloroquine resistance transporter (pfcrt) gene among chloroquineresistant parasite isolates. Am J Trop Med Hyg 2003, 68:398-402.

16. Johnson DJ, Fidock DA, Mungthin M, Lakshmanan V, Sidhu AB, Bray PG, Ward SA: Evidence for a central role for PfCRT in conferring Plasmodium falciparum resistance to diverse antimalarial agents. Mol Cell 2004, 15:867-877.

17. Picot S, Olliaro P, de Monbrison F, Bienvenu AL, Price RN, Ringwald P: A systematic review and meta-analysis of evidence for correlation between molecular markers of parasite resistance and treatment outcome in falciparum malaria. Malar J 2009, 8:89.

18. Sibley CH, Hyde JE, Sims PF, Plowe CV, Kublin JG, Mberu EK, Cowman AF, Winstanley PA, Watkins WM, Nzila AM: Pyrimethamine-sulfadoxine resistance in Plasmodium falciparum: what next? Trends Parasitol 2001, 17:582-588.

19. Zhang Y, Meshnick SR: Inhibition of Plasmodium falciparum dihydropteroate synthetase and growth in vitro by sulfa drugs. Antimicrob Agents Chemother 1991, 35:267-271.

20. Basco LK, Ringwald P: Molecular epidemiology of malaria in Yaoundé, Cameroon. III. Analysis of chloroquine resistance and point mutations in the multidrug resistance 1 ( $p f m d r 1$ ) gene of Plasmodium falciparum. Am J Trop Med Hyg 1998, 59:577-581.
21. Duraisingh MT, Drakeley CJ, Muller O, Bailey R, Snounou G, Targett GA, Greenwood BM, Warhurst DC: Evidence for selection for the tyrosine-86 allele of the pfmdr 1 gene of Plasmodium falciparum by chloroquine and amodiaquine. Parasitology 1997, 114:205-211.

22. Foote, Kyle DE, Martin RK, Oduola AM, Forsyth K, Kemp DJ, Cowman AF: Several alleles of the multidrug-resistance gene are closely linked to chloroquine resistance. Nature 1990, 345:255-258.

23. Grobusch MP, Adagu IS, Kremsner PG, Warhurst DC: Plasmodium falciparum: in vitro chloroquine susceptibility and allele-specific PCR detection of Pfmdr1 Asn86Tyr polymorphism in Lambarene, Gabon. Parasitology 1998, 116:211-217.

24. Menard D, Yapou F, Manirakiza A, Djalle D, Matsika-Claquin MD, Talarmin A Polymorphisms in pfcrt, pfmdr1, dhfr genes and in vitro responses to antimalarials in Plasmodium falciparum isolates from Bangui, Central African Republic. Am J Trop Med Hyg 2006, 75:381-387

25. Marfurt J, Muller I, Sie A, Oa O, Reeder JC, Smith TA, Beck HP, Genton B: The usefulness of twenty-four molecular markers in predicting treatment outcome with combination therapy of amodiaquine plus sulphadoxinepyrimethamine against falciparum malaria in Papua New Guinea. Malar J 2008, 7:61

26. Ruetz S, Delling U, Brault M, Schurr E, Gros P: The pfmdr1 gene of Plasmodium falciparum confers cellular resistance to antimalarial drugs in yeast cells. Proc Natl Acad Sci USA 1996, 93:9942-9947.

27. Reed MB, Saliba KJ, Caruana SR, Kirk K, Cowman AF: Pgh1 modulates sensitivity and resistance to multiple antimalarials in Plasmodium falciparum. Nature 2000, 403:906-909.

28. Pillai DR, Hijar G, Montoya I, Marquino W, Ruebush TK, Wrongsrichanalai C, Kain KC: Lack of prediction of mefloquine and mefloquine-artesunate treatment outcome by mutations in the Plasmodium falciparum multidrug resistance 1 (pfmdr1) gene for $P$. falciparum malaria in Peru. Am J Trop Med Hyg 2003, 68:107-110.

29. Price RN, Cassar C, Brockman A, Duraisingh M, van Vugt M, White NJ, Nosten F, Krishna S: The pfmdr1 gene is associated with a multidrugresistant phenotype in Plasmodium falciparum from the Western border of Thailand. Antimicrob Agents Chemother 1999, 43:2943-2949.

30. Duraisingh MT, Jones $P$, Sambou I, von Seidlein L, Pinder M, Warhurst DC: The tyrosine- 86 allele of the pfmdr 1 gene of Plasmodium falciparum is associated with increased sensitivity to the anti-malarials mefloquine and artemisinin. Mol Biochem Parasitol 2000, 108:13-23.

31. Duraisingh MT, Roper C, Walliker D, Warhurst DC: Increased sensitivity to the antimalarials mefloquine and artemisinin is conferred by mutations in the pfmdr1 gene of Plasmodium falciparum. Mol Microbiol 2000, 36:955-961.

32. Cowman AF, Galatis D, Thompson JK: Selection for mefloquine resistance in Plasmodium falciparum is linked to amplification of the pfmdr1 gene and cross-resistance to halofantrine and quinine. Proc Natl Acad Sci USA 1994, 91:1143-1147.

33. Peel SA, Bright P, Yount B, Handy J, Baric RS: A strong association between mefloquine and halofantrine resistance and amplification, overexpression, and mutation in the P-glycoprotein gene homolog (pfmdr) of Plasmodium falciparum in vitro. Am J Trop Med Hyg 1994, 51:648-658

34. Lim P, Alker AP, Khim N, Shah NK, Incardona S, Doung S, Yi P, Bouth DM, Bouchier C, Puijalon OM, Mesnick SR, Wrongsrichanalai C, Fandeur T, LeBras J, Ringwald P, Ariey F: Pfmdr1 copy number and arteminisin derivatives combination therapy failure in falciparum malaria in Cambodia. Malar $J$ 2009, 8:11.

35. Phompradit $P$, Wisedpanichkij R, Muhamad P, Chaijaroenkul W, NaBangchang K: Molecular analysis of pfatp6 and pfmdr1 polymorphisms and their association with in vitro sensitivity in Plasmodium falciparum isolates from the Thai-Myanmar border. Acta Trop 2011, 120:130-135.

36. Sidhu ABS, Uhlmann AC, Valderramos SG, Valderramos JC, Krishna S, Fidock DA: Decreasing pfmdr1 copy number in Plasmodium falciparum malaria heightens susceptibility to mefloquine, lumefantrine, halofantrine, quinine, and artemisinin. J Infect Dis 2006, 194:528-535.

37. Veiga MI, Ferreira PE, Jornhagen L, Maimberg M, Kone A, Schmidt BA, Petzold M, Bjorkman A, Nosten F, Gil JP: Novel polymorphisms in Plasmodium falciparum $\mathrm{ABC}$ transporter genes are associated with major ACT antimalarial drug resistance. PLoS One 2011, 6:20212.

38. Dondorp AM, Nosten F, Yi P, Das D, Phyo AP, Tarning J, Lwin KM, Ariey F, Hanpithakpong W, Lee SJ, Ringwald P, Silamut K, Imwrong M, Chotivanish K, 
Lim P, Herdman T, An SS, Yeung S, Singhasivanon P, Day NPJ, Lindegardh N, Socheat D, White NJ: Artemisinin resistance in Plasmodium falciparum malaria. N Engl J Med 2009, 361:455-467.

39. Noedl H, Se Y, Sriwichai S, Schaecher K, Teja-Isavadharm, Smith B, Rutvisuttinunt W, Bethell D, Surasri S, Fukuda MM, Socheat D, Chan Thap L: Artemisinin resistance in Cambodia: a clinical trial designed to address an emerging problem in Southest Asia. Clin Infect Dis 2010, 51:82-89.

40. Tinto H, Ouédraogo JB, Erhart A, van Overmeir C, Dujardin JC, van Marck E, Guiguemdé TR, D'Alessandro U: Relationship between the Pfcrt T76 and the Pfmdr-1 Y86 mutations in Plasmodium falciparum and in vitro/in vivo chloroquine resistance in Burkina Faso, West Africa. Infect Genet Evol 2003, 3:287-292

41. Basco LK, Ringwald P: Molecular epidemiology of malaria in Cameroon.X. Evaluation of Pfmdr1 mutations as genetic markers for resistance to amino alcohols and artemisinin derivatives. Am J Trop Med Hyg 2002, 66:667-671.

42. Parola P, Pradines B, Simon F, Carlotti MP, Minodier P, Ranjeva MP, Badiaga S, Bertaux L, Delmont J, Morillon M, Silai R, Brouqui P, Parzy D: Antimalarial drug susceptibility and point mutations associated with resistance in 248 Plasmodium falciparum isolates imported from Comoros to Marseille. Am J Trop Med Hyg 2007, 77:431-437.

43. Djimdé A, Doumbo OK, Cortese JF, Kayentao K, Doumbo S, Diourté Y, Dicko A, Su XZ, Nomura T, Fidock DA, Wellems TE, Plowe CV: A molecular marker for chloroquine-resistant falciparum malaria. N Engl J Med 2001, 344:257-263.

44. Niang M, Marrama L, Ekala MT, Gaye A, Tall A, Ndiaye JL, Sarr D, Dangou JM, Lehesran JY, Bouchier C, Mercereau-Puijalon O, Jambou R: Accumulation of CIEVT Pfcrt allele of Plasmodium falciparum in placenta of pregnant women living in an urban area of Dakar, Senegal. J Antimicrob Chemother 2008, 62:921-928.

45. Thomas SM, Ndir O, Dieng T, Mboup S, Wypij D, Maguire JH, Wirth DF: In vitro chloroquine susceptibility and PCR analysis of pfcrt and pfmdr1 polymorphisms in Plasmodium falciparum isolates from Senegal. Am J Trop Med Hyg 2002, 66:474-480.

46. Sarr O, Myrick A, Daily J, Diop BM, Dieng T, Ndir O, Salif Sow P, Mboup S, Wirth DF: In vivo and in vitro analysis of chloroquine resistance in Plasmodium falciparum isolates from Senegal. Parasitol Res 2005, 97: 136-140.

47. Sarr O, Ahouidi AD, Ly O, Daily JP, Ndiaye D, Ndir O, Mboup S, Wirth DF: Mutations in PfCRT K76T do no correlate with sulfadoxinepyrimethamine-amodiaquine failure in Pikine. Parasitol Res 2008, 103: 765-769.

48. Henry M, Diallo I, Bordes J, Ka S, Pradines B, Diatta B, M'Baye PS, Sane M, Thiam M, Gueye PM, Wade B, Touze JE, Debonne JM, Rogier C, Fusai T: Urban malaria in Dakar, Senegal: chemosusceptibility and genetic diversity of Plasmodium falciparum isolates. Am J Trop Med Hyg 2006, 75:146-151.

49. Bertin G, Ndam NT, Jafari-Guemouri S, Fievet N, Renart E, Sow S, Le Hesran JY, Deloron P: High prevalence of Plasmodium falciparum pfcrt K76T mutation in pregnant women taking chloroquine prophylaxis in Senegal. J Antimicrob Chemother 2005, 55:788-791.

50. Pradines B, Rogier C, Fusai T, Tall A, Trape JF, Doury JC: In vitro activity of artemether against African isolates (Senegal) of Plasmodium falciparum in comparison with standard antimalarial drugs. Am J Trop Med Hyg 1998, 58:354-357.

51. Pradines B, Tall A, Parzy D, Spiegel A, Fusai T, Hienne R, Trape JF, Doury JC: In vitro activity of pyronaridine and amodiaquine against African isolates (Senegal) of Plasmodium falciparum in comparison with standard antimalarial agents. J Antimicrob Chemother 1998, 42:333-339.

52. Pradines B, Tall A, Ramiandrasoa F, Spiegel A, Sokhna C, Fusai T, Mosnier J, Daries W, Trape JF, Kunesch G, Parzy D, Rogier C: In vitro activity of ironbinding compounds against Senegalese isolates of Plasmodium falciparum. J Antimicrob Chemother 2006, 57:1093-1099.

53. Pradines B, Tall A, Rogier C, Spiegel A, Mosnier J, Marrama L, Fusai T, Millet $P$, Panconi $E$, Trape JF, Parzy D: In vitro activities of ferrochloroquine against 55 Senegalese isolates of Plasmodium falciparum in comparison with those of standard antimalarial drugs. Trop Med Int Health 2002, 7:265-270.

54. Fall B, Diawara S, Sow K, Baret E, Diatta B, Fall KB, Mbate PS, Fall F, Diémé $Y$, Rogier C, Wade B, Bercion R, Pradines B: Ex vivo susceptibility of Plasmodium isolates from Dakar, Senegal, to seven standard anti-malarial drugs. Malar J 2011, 10:310.
55. Ndiaye D, Patel V, Demas A, LeRoux M, Ndir O, Mboup S, Clardy J, Lakshmanan V, Daily JP, Wirth DF: Short report: an non-radioactive DAPIbased high-throughput in vitro assay to assess Plasmodium falciparum responsiveness to antimalarials - Increased sensitivity of $P$. falciparum to chloroquine in Senegal. Am J Trop Med Hyg 2010, 82:228-230.

56. Gardella F, Assi S, Simon F, Bogreau H, Eggelte T, Ba F, Foumane V, Henry MC, Traore Kientega P, Basco L, Trape JF, Lalou R, Martelloni M, Desbordes M, Baragatti M, Briolant S, Almeras L, Pradines B, Fusai T, Rogier C: Antimalarial drug use in general populations of tropical Africa. Malar J 2008, 7:124.

57. Frosch AEP, Venkatesan M, Laufer MK: Patterns of chloroquine use and resistance in sub-Saharan Africa: a systematic review of household survey and molecular data. Malar J 2011, 10:116.

58. Kublin JG, Cortese JF, Njunju EM, Mukadam RA, Wirima JJ, Kazembe PN, Djimdé AA, Kouriba B, Taylor TE, Plowe CV: Remergence of chloroquinesensitive Plasmodium falciparum malaria after cessation of chloroquine in Malawi. J Infect Dis 2003, 187:1870-1875.

59. Laufer MK, Thesing PC, Eddington ND, Masonga R, Dzinjalamala FK, Takala SL, Taylor TE, Plowe CV: Return of chloroquine antimalarial efficacy in Malawi. N Engl J Med 2006, 355:1959-1966.

60. Noranate N, Durand R, Tall A, Marrama L, Spiegel A, Sokhna C, Pradines B, Cojean S, Guillotte M, Bischoff E, Ekala MT, Bouchier C, Fandeur T, Ariey F, Patarapotikul J, Le Bras J, Trape JF, Rogier C, Mercereau-Puijalon O: Rapid dissemination of Plasmodium falciparum drug resistance despite strictly controlled antimalarial use. PLOS One 2007, 1:139.

61. Ndiaye D, Dailly JP, Sarr O, Ndir O, Gaye O, Mboup S, Wirth DF: Mutations in Plasmodium falciparum dihydrofolate reductase and dihydropteroate synthase genes in Senegal. Trop Med Int Health 2005, 10:1176-1179.

62. Faye B, Ndiaye M, Ndiaye $J$, Annie A, Tine RC, Collé Lo A, Ndiaye M, Sow D, De Sousa A, Gaye O: Prevalence of molecular markers of Plasmodium falciparum resistance to sulfadoxine-pyrimethamine during the intermittent preventive treatment in infants coupled with expanded program immunization in Senegal. Parasitol Res 2011, 109:133-138.

63. Nelson AL, Purfield A, McDaniel P, Uthaimongkol N, Buathong N Sriwichai S, Miller RS, Wrongsrichanalai C, Mesnick S: pfmdr1 genotyping and in vivo mefloquine resistance on the Thai-Myanmar border. Am J Trop Med Hyg 2005, 72:586-592.

64. Witkowski B, Nicolau ML, Soh PN, Iriart X, Menard S, Alvarez M, Marchou B, Magnaval JF, Benoit-Vical F, Berry A: Plasmodium falciparum isolates with increased pfmdr1 copy number circulate in West Africa. Antimicrob Agents Chemother 2010, 54:3049-3051.

65. Witkowski B, Iriart X, Soh PN, Menard S, Alvarez M, Naneix-Laroche V, Marchou B, Magnaval JF, Benoit-Vical F, Berry A: pfmdr1 amplification associated with clinical resistance to mefloquine in West Africa: implications for efficacy of artemisinin combination therapies. J Clin Microbiol 2010, 48:3797-3799.

66. Holmgreen G, Bjorkman A, Gil JP: Amodiaquine resistance is not related to rare findings of Pfmdr1 gene amplifications in Kenya. Trop Med Int Health 2006, 11:1808-1812.

67. Sosowath C, Ferreira PE, Bustamante LY, Dahldtrom S, Martensson A, Bjorkman A, Krishna S, Gil JP: The role of pfmdr1 in Plasmodium falciparum tolerance to artemether-lumefantrine in Africa. Trop Med Int Health 2007, 12:736-742.

68. Mungthin M, Khositnithikul R, Sitthichot N, Suwandittakal N, Wattanaveeradej V, Ward SA, Na-Bangchang K: Association between the pfmdr1 gene and in vitro artemether and lumefantrine sensitivity in Thai isolates of Plasmodium falciparum. Am J Trop Med Hyg 2010, 83:1005-1009.

69. Pradines B, Tall A, Fusai T, Spiegel A, Hienne R, Rogier C, Trape JF, Le Bras J, Parzy D: In vitro activities of benflumetol against 158 Senegalese isolates of Plasmodium falciparum in comparison with those of standard antimalarial drugs. Antimicrob Agents Chemother 1999, 43:418-420.

70. Faye B, Offianan AT, Ndiaye JL, Tine RC, Touré W, Djorman K, Sylla K, Ndiaye PS, Penali L, Gaye O: Efficacy and tolerability of artesunate-amodiaquine (Camoquin plus) versus artemether-lumefantrine (Coartem) against uncomplicated Plasmodium falciparum malaria: multisite trial in Senegal and Ivory Coast. Trop Med Int Health 2010, 15:608-613.

71. Ndiaye JL, Faye B, Gueye A, Tine R, Ndiaye D, Tchania C, Ndiaye I, Barry A, Cissé B, Lameyre V, Gaye O: Repeated treatment of recurrent uncomplicated Plasmodium falciparum malaria in Senegal with fixeddose artesunate plus amodiaquine versus fixed-dose artemether plus lumefantrine: a randomized, open-label trial. Malar J 2011, 10:237. 
72. Yavo W, Faye B, Kuete T, Djohan V, Oga SA, Kassi RR, Diatta M, Ama MV, Tine R, Ndiaye JL, Evi JB, Same-Ekobo A, Faye O, Koné M: Multicentric assessment of the efficacy and tolerability of dihydroartemisininpiperaquine compared to artemether-lumefantrine in the treatment of uncomplicated Plasmodium falciparum malaria in sub-Saharan Africa. Malar J 2011, 10:198.

73. Basco LK, Le Bras J, Rhoades Z, Wilson CM: Analysis of pfmdr1 and drug susceptibility in fresh isolates of Plasmodium falciparum from subSaharan Africa. Mol Biochem Parasitol 1995, 74:157-166.

74. Shah NK, Alker AP, Sem R, Susanti Al, Muth S, Maguire JD, Duong S, Ariey F, Meshnick SR, Wrongsrichanalai C: Molecular surveillance for multidrugresistant Plasmodium falciparum, Cambodia. Emerg Infect Dis 2008, 14:1637-1640

75. Holmgren G, Gil JP, Ferreira PM, Veiga MI, Obonyo CO, Bjorkman A: Amodiaquine resistant Plasmodium falciparum malaria in vivo is associated with selection of pfcrt $76 \mathrm{~T}$ and pfmdr1 86Y. Infect Gen Evol 2006, 6:309-314.

76. Nsobya SL, Dokomajilar C, Joloba M, Dorsey G, Rosenthal PJ: Resistancemediating Plasmodium falciparum pfcrt and pfmdr1 alleles after treatment with artesunate-amodiaquine in Uganda. Antimicrob Agents Chemother 2007, 51:3023-3025.

77. Echeverry DF, Holmgren G, Murillo C, Higuita JC, Gil JP, Osorio L: Polymorphisms in the pfcrt and pfmdr1 genes of Plasmodium falciparum and in vitro susceptibility to amodiaquine and desethylamodiaquine. Am J Trop Med Hyg 2007, 77:1034-1038.

78. Danquah I, Coulibaly B, Meissner P, Petruschke I, Muller O, Mockenhaupt FP: Selection of pfmdr1 and pfcrt alleles in amodiaquine treatment failure in north-western Burkina Faso. Acta Trop 2010, 114:33-63.

79. Pradines B, Mabika Mamfoumbi M, Tall A, Sokhna C, Koeck JL, Fusai T, Mosnier J, Czarnecki E, Spiegel A, Trape JF, Kombila M, Rogier C: In vitro activity of tafenoquine against the asexual blood stages of Plasmodium falciparum isolates from Gabon, Senegal, and Djibouti. Antimicrob Agents Chemother 2006, 50:3225-3226.

80. Agnamey P, Brasseur P, Eldin De Pecoulas P, Vaillant M, Olliaro P: Plasmodium falciparum in vitro susceptibility to antimalarial drugs in Casamance (Southwestern Senegal) during the first 5 years of routine use of artesunate-amodiaquine. Antimicrob Agents Chemother 2006 50:1531-1534.

81. Ndiaye JL, Faye B, Diouf AM, Kuété T, Cisse M, Seck PA, Brasseur P, SameEkobo A, Lameyre V, Gaye O: Randomized, comparative study of the efficacy and safety of artesunate plus amodiaquine, administered as a single daily intake versus two daily intakes in the treatment of uncomplicated falciparum malaria. Malar J 2008, 7:16.

82. Ndiaye JL, Randrianarivelojosia M, Sagara I, Brasseur P, Ndiaye I, Faye B, Randrianasolo L, Ratsimbasoa A, Forlemu D, Ama Moor V, Traore A, Dicko Y, Dara N, Lameyre V, Diallo M, Djimdé A, Same-Ekobo A, Gaye O: Randomized, multicentre assessment of the efficacy and safety of ASAQ - a fixed dose artesunate-amodiaquine combination therapy in the treatment of uncomplicated Plasmodium falciparum malaria. Malar J 2009, 8:125.

83. Noedl H, Se Y, Schaecher K, Smith BL, Socheat D, Fukuda MM: Evidence of artemisinin-resistant malaria in western Cambodia. N Engl J Med 2008, 359:2619-2620.

84. Sibley $\mathrm{CH}$, Barnes $\mathrm{Kl}$, Plowe $\mathrm{CV}$ : The rationale and plan for creating a World Antimalarial Resistance Network (WARN). Malar J 2007, 6:118.

85. Sibley $\mathrm{CH}$, Barnes Kl, Watkins WM, Plowe CV: A network to monitor antimalarial drug resistance: a plan for moving forward. Trends Parasitol 2008, 24:43-48.

doi:10.1186/1475-2875-11-197

Cite this article as: Wurtz et al:: Prevalence of molecular markers of Plasmodium falciparum drug resistance in Dakar, Senegal. Malaria Journal 2012 11:197.

\section{Submit your next manuscript to BioMed Central and take full advantage of:}

- Convenient online submission

- Thorough peer review

- No space constraints or color figure charges

- Immediate publication on acceptance

- Inclusion in PubMed, CAS, Scopus and Google Scholar

- Research which is freely available for redistribution

Submit your manuscript at www.biomedcentral.com/submit 